UDC 111.1:398.22

Arusyak GHARIBYAN

\title{
ONTOLOGICAL PROBLEMS IN THE ARMENIAN NATIONAL EPIC "DAREDEVILS OF SASSOUN" (SASNA DZRER)
}

\begin{abstract}
The heroic epic reflects the attitude, thoughts, and dreams of each nation. It seems like a peculiar repository, which accumulates values, expectations, and worldview forms of the nation. Being the result of a synthesis of mythological and historical ones, the epic contains not only its traits but also philosophical outlook. Specifically, the philosophical concerns are very important and precious, as they express the main nature of the being and give answers to the question of a fundamental principle of the world, especially the concept of substance. The purpose of this article is to inference ontological notions hidden in layers of Armenian national epic. The investigation of national epic from such aspects opens widespread ranges for discovering its mysteries. In the heroic epic, the Armenians reflect not only their past but also their statements about substantial principles, the mutual relation between the matter and the spiritual. In the Armenian epic "Daredevils of Sassoun" the water is a fundamental substance which gets its property only by the will of supernatural forces (God, angels, etc.). Thereby, the Armenian epic "Daredevils of Sassoun" expresses a peculiar conception which is directly related to ontological issues.
\end{abstract}

Keywords: heroic epic, epic hero, worldview, philosophy, ontology, water, substance, being, God.

\section{Introduction}

Investigation of a heroic epic noticeably assists not only to researchers of national literature but also to disclosure and understanding of moral values and philosophical outlook of the nation. The epic illustrates the attitude, thoughts, and dreams of each nation. An epic may deal with such various subjects as myths, heroic legends, histories, edifying religious tales, animal stories, or philosophical or moral theories. Epic poetry has been and continues to be used by peoples all over the world to transmit their traditions from one generation to another ("The New Encyclopedia Britannica in 30 Volumes", 1977). It also accumulates national expectations and worldview forms in a peculiar way. Being the result of the synthesis of mythological and historical ones, the epic contains not only those traits but also the archetypes of the national identity and philosophy.

An ambiguous term, "epic" is used most often to designate a long narrative poem recounting heroic deeds. In literary usage, the term encompasses both oral and written compositions. These traditions often include legendary narratives about the notable deeds of 
their national heroes ("The New Encyclopedia Britannica in 30 Volumes", 1977). Though the braveness and heroism are the main characteristics of the epic hero, there are some peculiar features, which differ heroes from each other. In this regard, the exploration of the epic becomes more important and contributes to revealing the main traits of national consciousness and philosophical concepts. The epic is a vital past of the people in the framework of heroic idealization. From here the epic acquires its scientific, historical value and at the same time its great public, cultural and educational value (Zhirmunsky, 1962, p. 196). The investigation of national epic from such aspects opens widespread ranges for discovering its mysteries. Specifically, an epic contains philosophical concerns, that is very important and precious, as they express the main nature of the being and gives answers to the question of a fundamental principle of the world, especially the concept of substance. The article will focus on such problems in the Armenian national epic "Daredevils of Sassoun".

The Armenian heroic epic "Daredevils of Sassoun" is an outstanding poetic work reasonably associated with the very spirit of the Armenian people and its historical destiny. On 5 Dec 2012 the epic poem Daredevils of Sassoun was included on UNESCO Intangible Cultural Heritage list. The epic was orally delivered over the centuries (approximately from IX centuries), and it was only recorded for the first time in 1873 by Bishop G. Srvandzatyan. Despite the act of its recording in a relatively late period, immediately after its recognition the poem had a great influence on the Armenian mind, literature and ideological patterns (Zolyan, 2014, pp. 55-56). The Armenian national epic Daredevils of Sassoun, also known as David of Sassoun ("Sasountsi Davit" or "Tavit" in Armenian), among other titles. It is a long poem in four cycles (parts), following four generations of a family, of which David is the third, being preceded by Sanasar and Baghdasar, then the Great Mher ("Mets" or "Medz Mher", also known as "Lion Mher"), ending with Little Mher ("Pokr Mher"). In keeping with epics all over the world, the story involves fantastic exploits and incredible adventures, within an overarching theme of good versus evil and fighting for justice.

Although the epic itself is dated to the 8th-10th centuries - especially as the struggle against Arab rule of that era is a clear detail many elements of the Sassoun cycles involve far more ancient aspects, including relics of pagan Armenian culture. Popular memories of competitions and battles between Armenian and Mesopotamian rulers a millennium before Christ may have been transformed in medieval times using the Caliph of Baghdad or the King of Egypt as the target instead ${ }^{1}$. In addition the historical events, that had great impact on the formation of the epic, the epic contains mythological elements. Thought, there are "vagrant plots" in various epics, which mainly repeat the plot, each national epic highlights the main characteristics of national worldview points. It frequently reflects the cosmogonic notions and outlook of the nation.

\footnotetext{
1 http://100years100facts.com/facts/armenianepic-daredevils-sassoun-first-put-paper-1873/
} 
In the Armenian national epic "Daredevils of Sassoun" (Sasna Dzrer ${ }^{2}$ ) it is possible to find such notions of the ancient Armenians. In the heroic poetry, the greatest heroes are thought to be so wonderful that they cannot be wholly human but must have something divine about them. Whatever a hero's birth may be, and of course it is mainly natural enough, he is known from the start as an uncommon being whose evolution and characteristics are not those of other men. There is about him something predetermines, and presage of glory accompany his birth (Bowra, 1952, pp. 94-95). The Armenian epic heroes Sanasar and Baghdasar have an extraordinary birth as well. The twins' mother Dzovinar, whose name connects her with water, drank one-and-a-half handfuls of the water and became pregnant:

"Dzovinar then invoked:

- Raise a spring here, O God, And guide me through Your light.

By God's will the lake parted then, A spring of sweet water appeared. In the pool near the bank she saw a big rock.

Water surrounded the rock,

No one, without disrobing,

Could reach the spring to drink its water,

Dzovinar took off her garments, swam to the spring.

She cupped her hands and drank a cupped handful

And half-a-cupped handful of water

From the life-giving (anmahagan) spring,

The spring then went dry.

2 See: David of Sassoun Armenian National Epic, Yerevan, 1961.
She conceived from the water

That she drank at the spring"

(Shalian, 1964, pp. 12-13).

So Sanasar and Baghdasar were born from a spring water of Katnaghbyur. The motif of the wonderful birth of the hero is one of the very widespread plots of folklore and, in particular, a fairy tale. But it is known not only for fairy tales. Immaculate conception is available as it is possible to judge, in all world religions - from the earliest and primitive ones, including Christianity (Propp, 2001, p. 65). Certainly, such motif is widespread in many ancient myths, tales, and epics, nevertheless, there are differences in the development of this motif in the different narrative and epic tradition, and these differences reflect the main peculiarities of the temper of the nation. For example in the Armenian national epic the epic heroes were born from the "special water"- the water, which appeared in the sea by the will of God. The difference between the "usual water" and "special, substantial water" in the epic is seen very distinctly. The water which gives birth differs from the "other water", it appears in the sea and the heroes in the epic are able to distinguish it. This is not a simple mythological belief of ancient Armenians. It is similar to Thales' water. According to Thales Miletus, the water is an active substance and source of life. In the heroic epic "Daredevils of Sassoun", the theme of the creating water is developing in further episodes of the first cycle of the epic:

"Sanasar said to Baghdasar:

- Brother let us go into the lake And see if we will sink. 
Baghdasar replied:

- Brother, life is sweet; I will not go into the lake.

Sanasar said to his brother:

- You stay here, I will go alone,

If I do not sink, you come,

But if I sink and drown, do not come,

You stay here and stay alive..."

(Propp, 2001, pp. 44-45).

Sanasar subconsciously plunged himself into the water. Such behavior seems very strange but it has weighty reasons. Carl Jung in his famous book "Archetypes and Collective Unconscious" provided an explanation for that: "Water is the commonest symbol for the unconscious. Water is the "valley spirit"... Psychologically, therefore, water means the spirit that has become unconscious..." (Jung, 1969, pp. 18-19). Unconsciously Sanasar tried to find his real identity and his natural existence.

"Going into the lake,

Sanasar walked as if he were on dry land.

He reached a garden at the bottom of the lake,

Where he saw a palace and pavilion, And a pool [in the garden].

... There he also saw a chapel.

As he entered the chapel, he looked around.

He fell asleep and had a dream.

The Mother of God appeared to him in his dream

And said: _ Arise, Sanasar, ... You will bathe in the palace pool, And you will grow, gather strength and courage..."

(Shalian, 1964, pp. 44-46).
Then Sanasar awoke, came out of the chapel, went to the pool and bathed, drank the water of the fountain and fell asleep:

"He slept for a while, attained the grace of God,

He grew, gathered strength, courage And become a fiery being..."

(Shalian, 1964, p. 47).

Then Sanasar took the wonderful armor of weapon and a fiery horse intended to him. Bagdasar couldn't recognize his brother after his alteration, as he became very strong and giant. As it was obvious, the epic sent the same message: there was water in the water (pool in the garden in the sea), and again we faced with the "special", forming water that gave power and chivalry. The epic prompts that there is a "special" water which gives birth and power.

The theme of the "special", forming water continues in another episode of the epic "Daredevils of Sassoun": the twin brothers got to one river and noticed something very strange and magnificent; there was a small stream in the river which was dividing the river into two parts. The brothers wondered:

"- how powerful that tiny stream must

be!

It cleaves the big river

And reaches the opposite bank.

... Baghdasar said to Sanasar:

- That water is aznantzordy water.

The man who drinks it at its source

Will become invincible,

No one will be able to down [overpower] him.

Sanasar then said to Baghdasar: 
- Whoever finds the source of that tiny stream

And builds his home at its site,

He will sire sons

As powerful as the water of that

stream..."

(Shalian, 1964, pp. 28-29).

Finally, they decided to find the spring and built their castle there. As it was mentioned previously, the same plot repeated in the epicseveral times: "water in the water", "special water", "life giving water", "anmahagan water", "aznantzordi water"- a message that helps to evaluate the importance of the substantial quality of the water. Consequently the epic shows the great importance of that "special" water and suggests the notion of its substantial quality.

Similar notions were declared in the theocentric cosmology of famous Armenian philosopher Anania Shirakatsi where God was uncreated, immobile and non-material. God, first of all, created 4 elements- water, air, fire, and earth. The elements create all other things (Arevshatyan, 2012, p. 69). The same ontological issue, as it is presented in the paper, exists in the Armenian national epic in which clearly underlines the dominating role of the idealistic outlook: water is substantial quality, but it gets its activity only from divine forces.

Generalizing, it is possible to note that all these "water-linked" notions include not only the traces of the mythological outlook of ancient Armenians and the water cult, but also philosophical essential concerns. The philosophical interpretations of natural phenomenon are illustrated in the Armenian national epic. These issues are the concerns that can be identified with a substance problem in the philosophy. The paradigm, presented in the epic, pre- requisites a development of the idealistic worldview that linked with water as something substantial and obtains its power only from divine plan. Such philosophical interpretation of discussed problem is mentioned in Rene Descartes' philosophy. According to him "the term substance is not applicable to God and the creatures in the same sense. But with regard to what we consider as things or the modes of things, it is worthwhile to examine each of them by itself. By substance, we can conceive nothing else than a thing which exists in such a way as to stand in need of nothing beyond itself in order to its existence. And, in truth, there can be conceived but one substance which is absolutely independent, and that is God. We perceive that all other things can exist only by the help of the concourse of God"3 Though we call Descartes dualistic philosopher, however, he accepted only unique, perfect substance - God, who is a creator of material and spiritual substances. Summarizing the results of the paper it is possible to declare that in above-mentioned episodes of the epic "Daredevils of Sassoun" (Sasna Dzrer) outline the ontological notions of the ancient Armenians, where water performs as a foundation of the all things, it is also mentioned as a substantial quality, which gives birth to heroes and endows them with invincible force. The "special water" is considered to be sacred and the heroes of Sassoun founded their castle on its sources. Though water gives strength, birth, power and luck and is considered as a substantial quality, there is an important fact that is outlined in the epic: all these come true only

3 See: Descartes, R. Principles of philosophy.

Retrieved from

http://www.fullbooks.com/The-Principles-of-

Philosophy1.html 
with the will of God. Thus, in the Armenian national epic water get its substantial quality only with the help of divine forces, which allow to supposing that water isn't perceived as self-dependent material substance. Such philosophical notions have been developed during the history of philosophy through the centuries.

\section{REFERENCES}

Arevshatyan, S. (2014). Anania Shirakacu bnap'ilisop'ayakan hayacqnery (Anania Shirakatsi's Natural Philosophical Views, in Armenian). "Astronomical Heritage in the National Culture" Archaeoastronomical Meeting Dedicated to Anania Shirakatsi's 1400th Anniversary and XI Annual Meeting of the Armenian Astronomical Society. Yerevan: Gitutyun, pp. 68-75.

Bowra, C. M. (1952). Heroic Poetry. London.

Descartes, R. Principles of philosophy. Retrieved from http://www.fullbooks.com/ThePrinciples-of-Philosophy1.html.
Jung, C. (1969). Archetypes and the Collective Unconscious, Princeton.

Propp, V. (2001). Skazka, epos, pesnya (Tale, Epic, Song, in Russian). Moscow.

Sasunci Davit' haykakan jhoghovrdakan e'pos (David of Sassoun Armenian National Epic, in Armenian). (1961). Yerevan.

Shalian, A. K. (1964). David of Sassoun. The Armenian Folk Epic in four Cycles. Athens.

The New Encyclopedia Britannica in 30 Volumes (1977). 15-th edition, Volume VI, USA.

Zhirmunsky, V. (1962). Narodnyi geroicheskii epos (National Heroic Epic, in Russian). Comparative-historical studies. Moscow.

Zolyan, S. (2014). The Daredevils of Sassoun: The Deep Structure of the Plot. Studia Metrica et Poetica 1.1. Retrieved from http://www.academia.edu/6901388/ DAREDEVILS OF SASSOUN 2014. 